\title{
コネクタ用スズめっきに必要な物性及び評価
}

\author{
瀧 川 雄 輝 ${ }^{\mathrm{a}}$ \\ a 石原ケミカル(株)( $=$ 652-0806 兵庫県神戸市兵庫区西柳原町 5-26)
}

\section{Physical Properties and Evaluation Required for Tin-plated Connector}

\section{Yuki TAKIGAWA ${ }^{a}$}

a Ishihara Chemical Co., LTD.(5-26, Nishi-yanagiwara-cho, Hyogo-ku, Kobe-shi, Hyogo 652-0806)

Keywords : Electro Plating, Connector, Evaluation Method

\section{1. はじめに}

コネクタとは, 複数の電子回路(ケーブル間や回路基板間, モジュールー回路基板間等)を電気的に接続するために使用 される部品の総称で, 様々な電子機器, 家電, 産業機械, 自 動車, 通信周辺機器等の内部に組み込まれている。機器部品 の組み立て工程に, はんだ付けや圧着等の接合を用いる場合 は接続部を分離, 再接続することは困難であるが, コネクタ を使用することにより手や治具を用いて安全かつ容易に脱着 可能であることは利点の一つである。上記理由からも, 昨今 の電子機器の組み立てにはコネク夕は必要不可欠な要素と なっている。

本稿ではそのコネクタにめっきを施したスズ皮膜に要求さ れる(1)ウィスカ特性，(2) はんだ濡れ性，（3）挿抜性，（4）接 触抵抗，(5) 微摺動摩耗特性，（6) 耐熱性・リフロー性，（7） 界面制御の 7 種類の物性とその評価方法を中心に解説する。

\section{2. 現 状}

コネクタを構成する部品は, 一般に電気を導通させる金属 部分とその周りの樹脂モールドやプラスチックなど非導電性 材料を使用した部分に分けられる。導通の役割を担う金属部 分としては主に銅または銅合金(リン青銅・ベリリウム銅・ 黄銅等)が用いられているが，酸化及び腐食を防止するため にその上に金属めっきを施すことが多い。めっき種としては

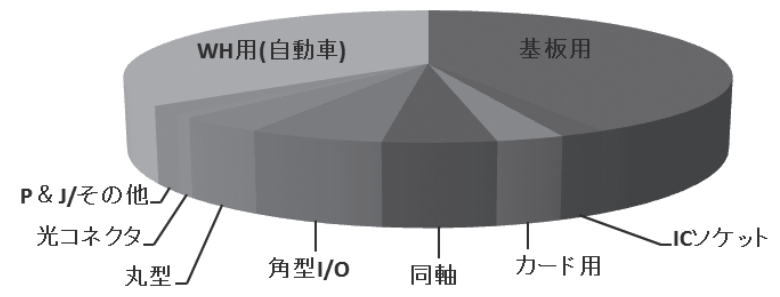

図 1 日系企業によるコネクタ生産額比率 (2015 年) ※ P\&J/他とはプラグジャック及びその他コネクタを 示す。
金めっきが最も多く，ついでスズめっき・リフロースズめっ きが多い。但し, 求められる物性に応じてスズ合金めっきを 施す場合もある。

図 1 に2015 年のコネクタ製品の用途別の生産額の割合を 示す ${ }^{1)}$ 。コネク夕の仕様・用途としては基板用のコネクタ及 び車載用のコネク夕の生産額が大部分を占めており, その中 でもワイヤーハーネス $(\mathrm{WH})$ 用を含む車載用コネクタの需要 は今後も増加する見通しとなっている。

\section{3. 要求物性及び評価方法}

\section{1 ウィスカ特性}

ウィスカとは, 金属表面にほぼ同じ太さの針状に伸びた金 属の単結晶を指し，スズウィスカにおいても同様の現象が見 られる。近年コネクタの多極化, 小型・軽量化によって端子 の間隔が狭くなっており，このスズウイスカによって端子間 の短絡を引き起こす可能性がある。故に電子機器の信頼性を 確保する上でもウイスカの抑制対策が最も重要な課題となっ ている。一般に, スズウィスカにはめっき皮膜の内部の応力 が要因となって発生するもの (内部応力型) と外部からの圧力 によって成長するもの(外部応力型)に大別される。内部応力 型に関しては，下地めっき処理またはスズ合金めっき化を行 うことで抑制できることが確認されている。一方，コネクタ 部品については内部応力型よりも, 嵌合の際に発生する負荷 が大きく影響する外部応力型のウィスカが発生することが多 く, このウィスカに関しては内部応力型で行う抑制方法では 効果は得られない。外部応力型ウィスカの試験評価を行うに

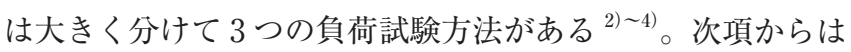
その具体例を記載する。

\section{1. 1 アクリル板による負荷試験}

図 2 に示すように評価サンプルのめっき面に透明アクリル 板を押しあて加圧することにより, 接触部付近のめっき部位 から数十時間で大量のスズウィスカの発生が確認できる。 図 3 に, 下地ニッケルめっきを $1 \mu \mathrm{m}$, その後スズ (リフロー スズ含む) 及び実製品で採用されているスズ合金めっきをそ れぞれ $3 \mu \mathrm{m}$ 施したリン青銅コネクタを上記方法で加圧した 
(加圧量 : $1.2 \mathrm{~N} \cdot \mathrm{m}$, 保持時間 $280 \mathrm{~h}$, 保管温度 $25^{\circ} \mathrm{C}$ ) 際に発 生したウイスカ及びその最大長を示す。試験皮膜がそれぞれ 無光沢〜半光沢〜光沢と異なるため, スズ皮膜とスズ合金皮 膜のウィスカ抑制の相対比較は困難ではあるが，スズ皮膜と 比較すると $\mathrm{Bi}, \mathrm{Ag}, \mathrm{Cu}$ を含有したスズ合金皮膜はウィスカ 抑制の効果が確認される。さらに，リフロースズ皮膜は均一 な膜厚で鏡面状に溶解していることが前提となるが，合金又 ズ皮膜よりもさらに良好な結果が得られた。なお，この試験 法は応力負荷の調節が難しく, 他の試験方法に比心加圧精度 は高くないが，ウイスカ抑制を目的としためっき開発におい て各条件の優位性を簡易に確認する方法として有効である。

3. 1. 2 圧子による荷重試験法

図 4 に示す装置は一定の重りを備えた各種(球状，円柱状， コネクタ接点状) 圧子でスズ皮膜を圧迫し, 圧痕周辺に発生 するウィスカを測定評価するものである。外部応力型ウィス カが確認されて以降，基礎的な試験方法として採用されてお
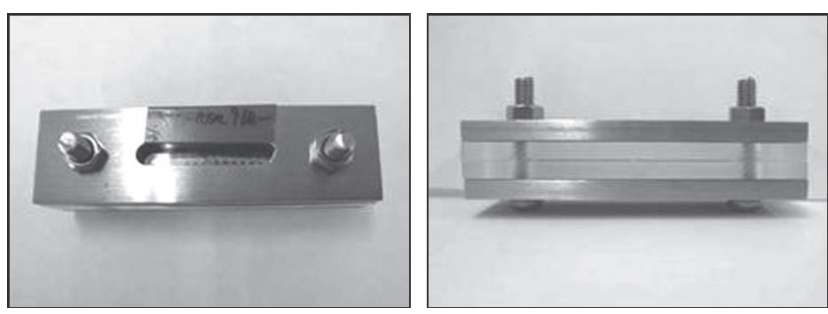

図 2 アクリル板による試験装置

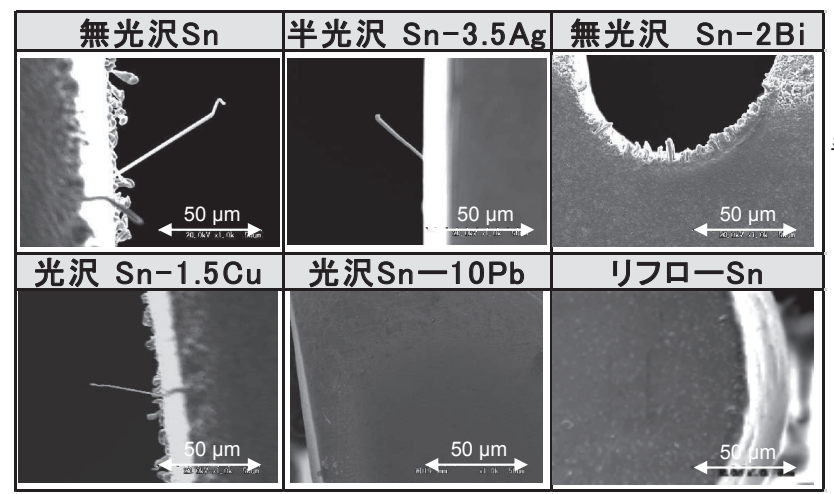

図 3 スズ系皮膜に㧍けるアクリル板での加圧試験後のウィスカ SEM 像 (左図)とその最大長(右図)

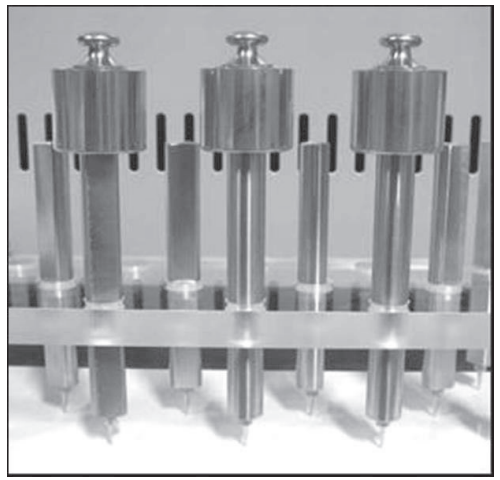

図 4 圧子による荷重装置
り，電子情報技術産業協会(JEITA) p日本電子回路工業会 (JPCA)などの工業界において標準化が進んでいる。図 5 は 圧痕試験 $(200 \mathrm{gf}$, 保持時間 $240 \mathrm{~h}$ ) 後のスズ皮膜とスズ - ビス マス皮膜の最大ウィスカ長の比較結果を示す。3.1.1で実施 した試験結果と同様の傾向が確認され，スズの合金化がウィ スカ対策として有効であることがわかる。本試験方法は，得 られるデー夕量は多くないが, 応力負荷状態を荷重や圧子形 状などで制御できるため, 外部応力によるウイスカ発生, 成 長予測の解析に有用な試験方法ともいえる。

3. 1. 3 コネクタ部品と基板の嵌合試験

本試験法は, 図 6 に示すようなコネクタ端子とフレキシブ ル基板の勘合時に勘合接点で発生するウイスカを評価する ${ }^{5)}$ 実際の製品の使用状態でウイスカを確認することができるた め, 特定部品の組み合わせによるウイスカ発生評価判断に用 いられる。また, 確認部品の接点数に応じてサンプル数が多 く得られることでウィスカ発生, 成長の傾向をとらえる場合 に有効である。ただし，コネクタ部品の接点形状や接点圧力 または相手材の硬さにより, めっき皮膜にかかる外部応力が 変化するため, めっき皮膜自身の耐ウイスカ性を判断するに はそれらの影響を考慮する必要がある。

\section{2 はんだ濡れ性}

端子・コネクタ部品とプリント基板の接続には，はんだ付 けが行われているが, 材料のはんだ需れ性(はんだ付け性)が 悪いとはんだ付けに時間を要したり，端子・コネク夕部品が プリント基板から外れるなどの問題が生じる。コネクタのは

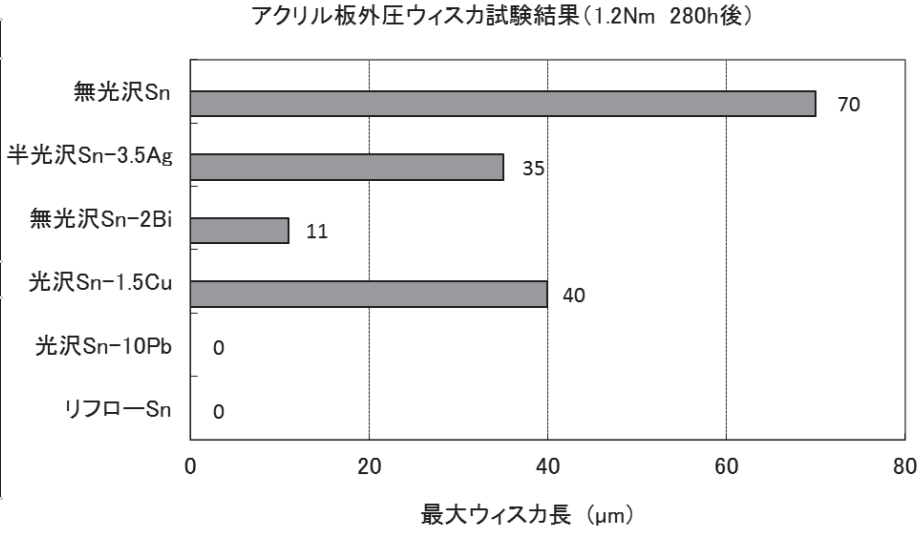

アクリル板外圧ウィスカ試験結果 (1.2Nm 280h後) 


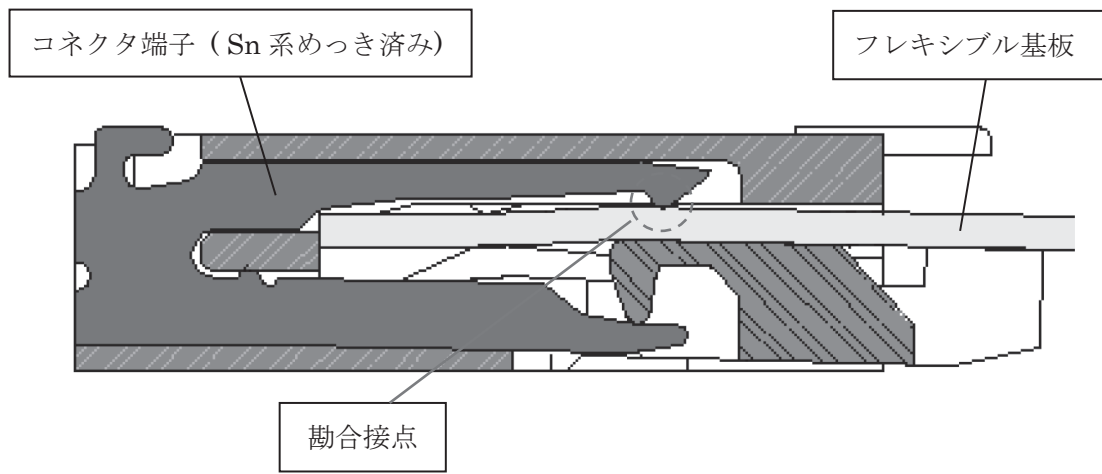

図 6 コネクタ端子とフレキシブル基板勘合時の構造例 (JEITA ET-7305 資料より)

んだ需れ性の評価としては，濡れ広がり法やメニスコグラフ 法が用いられている ${ }^{6)}$ 。特に, メニスコグラフ法はゼロクロ スタイムや濡れ応力を数值として把握でき, 信頼性の高い評 価方法である。はんだ需れ性は，はんだ付けの前処理段階と して用いられるフラックスやスズ皮膜の表面粒子の形状, 酸 化状態, 膜厚等に影響される。図 7 は膜厚を変化させて作製 したコネクタのプレッシャークッカー試験 $\left(105{ }^{\circ} \mathrm{C}, 100 \%\right.$, $4 \mathrm{~h}$ ) 後のはんだ需れ性(ゼロクロスタイム)を示す。はんだ需 れ性は膜厚 $5 \mu \mathrm{m}$ 以上で安定し良好な傾向を示すが，後述の 挿抜特性は悪化するため, 他の表面特性への考慮も必要であ る。また，図８に示すように，実際の測定サンプルのはんだ 浸漬箇所を観察し，はんだはじき等が無いかどうかを確認す る場合もある。この評価法は多種の製品のはんだ需れ性を簡 易的に評価する上で重要である。

\section{3 挿抜性}

前述のように近年ハイブリッド自動車や電気自動車の増加 によって，自動車一台あたりに使用されるワイヤーハーネス の数が増大している。従ってそれらを中継するためのコネク 夕一つ当たりの極数や接触荷重が増大している。そのため,

組み立ての際に作業者がコネクタを手作業で差込むときの挿 入力も増大し負担が大きくなっている。

挿抜性についてはコネクタ端子の形状や嵌合方法に影響さ れるが, コネク夕に施されるめっき皮膜の金属種にも影響さ

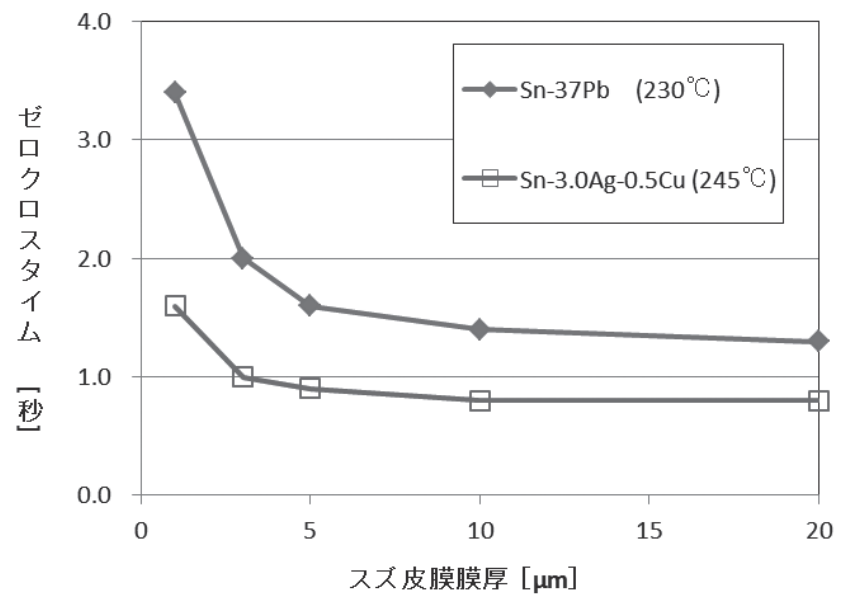

図 7 膜厚変化による PCT 後のゼロクロスタイム
れる。端子の扦入具体的には材料表面の硬さ, 摩擦係 数，端子の接圧等によって決まるため，スズ皮膜表面の硬度 及び摩擦係数を測定することにより評価することができる。 硬度の測定にはマイクロビッカース硬度計, 摩擦係数の測定 には一般に表面性測定機を用いる。皮膜硬度の維持として 3.1.1で選択したスズ及び各スズ合金めっきを銅板 (C1100P) に $5 \mu \mathrm{m}$ 施し, めっき初期から 10 日経過毎に皮膜硬度を測 定 (5 gf，保持時間 20 秒) した。皮膜硬度と経時日数による 関係を図 9 に示す。また, 図 10 に, 無光沢スズと光沢はん だめっきを施した銅板 $(\mathrm{C} 1100 \mathrm{P})$ 試験片に任意の荷重を加え た鋼球を接触させ，一定速度で摺動した際の摺動回数と摩擦 係数の関係を示す。一般に光沢はんだ皮膜のグレインサイズ は $0.05 \mu \mathrm{m}$ 以下の微細な粒子であり, 表面の凹凸も無光沢ス ズ皮膜に比べて小さいこと, ならびに皮膜が硬いことから 静・動摩擦係数共に低い結果が得られている。

なお，往復回数が少ない条件で摩擦係数が増大(特に無光 沢スズ皮膜)するのはスズ皮膜の削れやスズ同士の凝着が起 こるため一次的に摩擦係数が増大したものと考えられる。

\section{4 接触抵抗}

コネクタの最も重要な機能は, 電気信号や電力を劣化させ ることなく伝達することである。そのため, コネク夕を使用

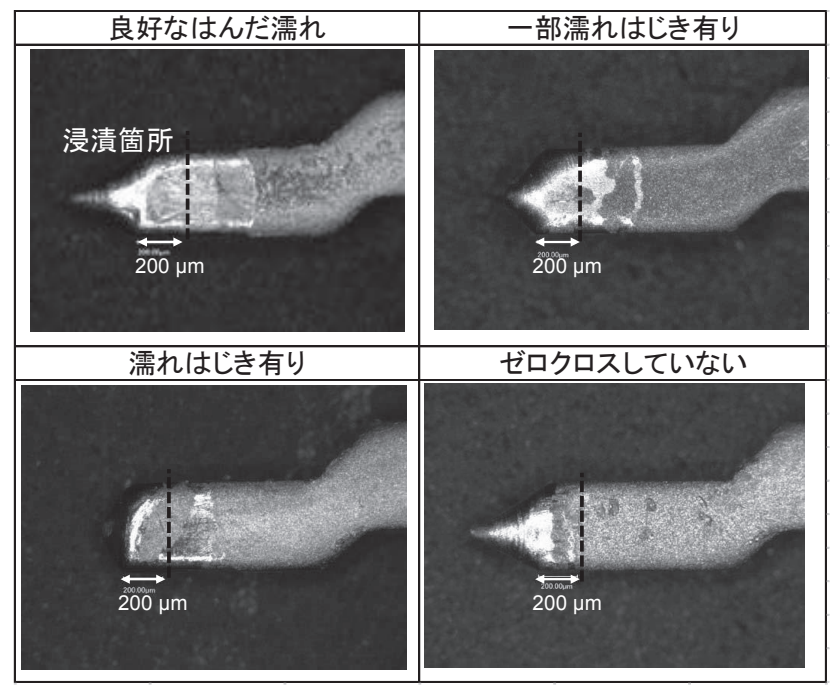

図８はんだ濡れ面積評価法 

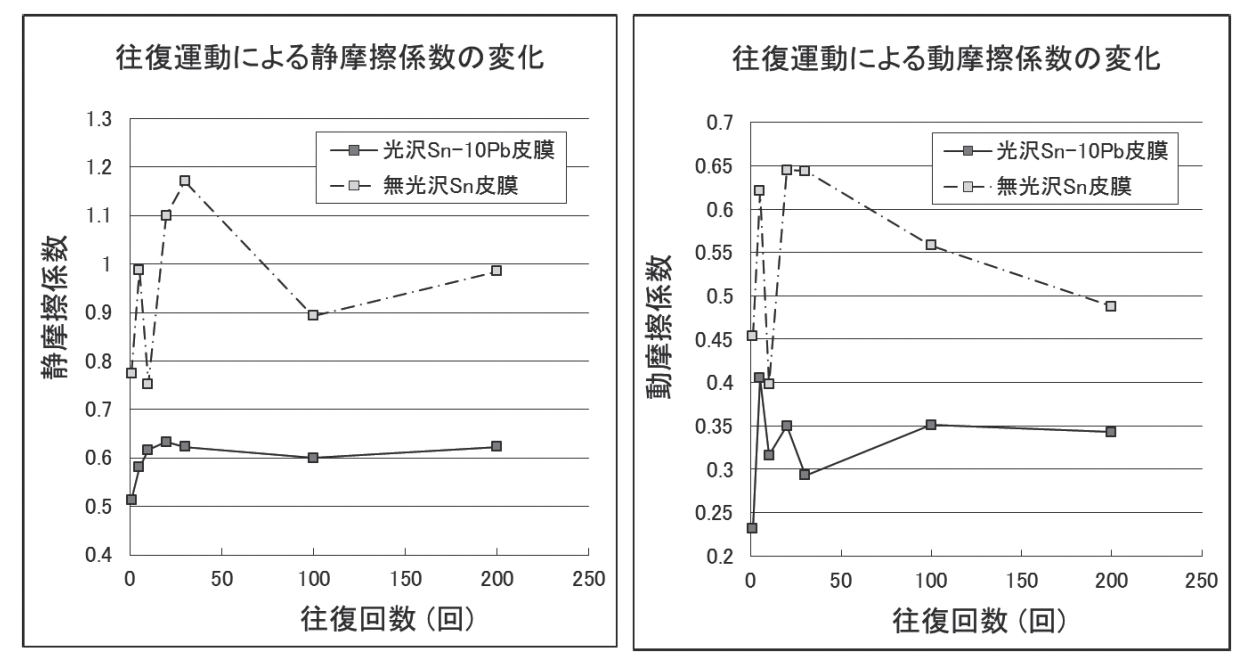

図 10 無光沢スズ及び光沢はんだ皮膜の摺動回数における静・動摩擦係数の推移
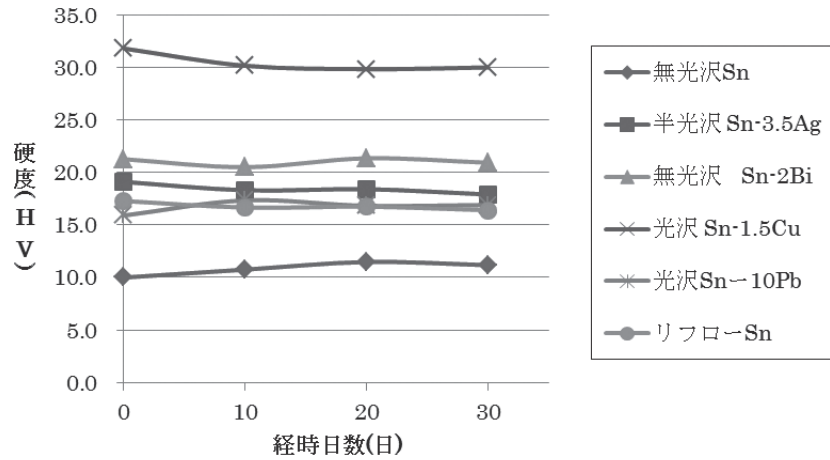

図 9 経時日数における皮膜硬度推移

する装置類の寿命を長期化させるためには接触抵抗を低く保 つことが重要となる。接触抵抗は接触する金属間に存在する 酸化膜などの皮膜による抵抗 (皮膜抵抗) と, 電流が集中する ことによる抵抗(集中抵抗)の和で示される。皮膜抵抗は酸化 皮膜の電気比抵抗や厚さに依存する。集中抵抗は実際の接触 面積に依存し，接圧，めっき皮膜の硬さ，及び酸化皮膜の硬 さに依存する。図 11 に3.1.1 で選択したスズ及び各スズ合金 皮膜の接触抵抗と測定時の荷重の関係を示す。いずれのめっ き皮膜も低荷重の場合に抵抗值が高い結果となっているのは, 表面に形成された酸化膜の影響及び接触面積が狭いことが要 因であると考えられる。

\section{5 微摺動摩耗特性}

微摺動摩耗現象とは, 接点に振動や衝撃などが加わって微 小な摺動が起きたとき，接点間の接触抵抗が急激に増大する 現象である。端子の小型化, 多極化に伴うコネクタ挿入力の 増大を抑えるため, コネク夕接点部の荷重を低減させること が望まれている。そのため, これまで問題にならなかった振 動や衝撃, 通電時の発熱による熱伸縮によって, 接点部にず れが生じやすくなっている。近年, 自動車のエンジンルーム に電子部品が搭載されることが多くなり，エンジンや路面状 態による振動や熱伸縮によるコネクタ接点部の摺動が発生し やすくなっており, 摺動摩耗の低減が今後重要な課題になる と考えられている。微摺動摩耗特性を測定する際には専用の 微摺動摩耗特性試験機を用いる場合が多いが，具体的にはサ

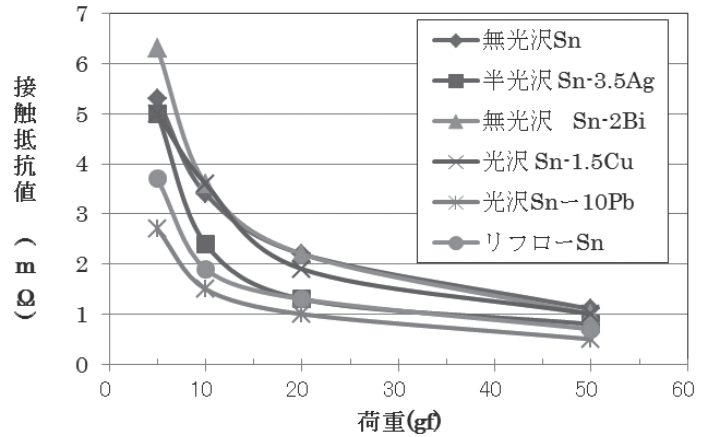

図 11 スズ及びスズ合金皮膜における荷重変化による接触抵抗值

ンプルに一定荷重を掛け，任意の摺動周波数，摺動距離にお いて摺動回数毎の接触抵抗を測定することで評価することが できる7)。

\section{6 耐熱性・リフロー性}

コネクタの実装工程において, 熱の過負荷によってスズ皮 膜の溶融時に変色やヨリ(皮膜の凹凸)等の問題が発生する場 合がある。スズ皮膜の耐熱性及びリフロー性の簡易評価方法 をそれぞれ記載する。耐熱試験においては $150 \sim 180{ }^{\circ} \mathrm{C}$ の恒 温炬内に数時間〜数百時間コネクタを放置し，光沢抜け・変 色等の外観の評価を行う。また，リフロー性の評価としては $250 \sim 300{ }^{\circ} \mathrm{C}$ の条件下で数分間ホットプレートもしくは熱風 炉を用いて繰り返し加熱し, 皮膜表面の光沢性, 変色, はじ きを確認する方法がある。また，実際のリフロー実装時の工 程 (昇温 $\rightarrow$ プレヒート $\rightarrow$ 本加熱 $\rightarrow$ 冷却)を再現するためにリフ ローシミュレーター装置を用いて, 実装温度や時間変化によ るリフロー外観の評価を行う場合もある。光沢性については 粒径(粒子の大きさ)や部材の熱伝導率や形状によって最適な 温度, 時間等が異なるため, 部材毎に最適条件の検証を行う ことが望ましい。

\section{7 界面制御}

コネクタの種類によっては勘合部分など必要な部分にのみ 皮膜特性を付与させるために，部分めっきを施すことも少な くない。部分めっきには, 液面の制御による方法, めっきを 施したい部分にノズル状の噴射口からめっき液を直接噴射す 
る方法, めっき皮膜の不要な部分をマスキングする方法など がある。部分めっきの場合，めっき皮膜の付き回りと呼ばれ る膜厚分布が重要になるために, めっき部と非めっき部の境 界面の幅や膜厚分布を測定することで界面の精度を評価する ことができる。この界面精度についてはめっき液と素材の界 面張力にも影響する。

\section{4. 今 後}

前述のように自動車の電装化の進展に伴ってユニット電子 部品搭載数は増大し，それらを結ぶ電気配線及びコネクタも 同様に増大してきている。しかし, 自動車に搭載される端子 コネクタ用材料に対しては, 組立工程における作業性に影響 する挿抜特性から自動車に搭載された後の電気的信頼性に至 るまでさまざまな要求があり, 周波数特性等, 上記で挙げた
物性以外についても考虑して開発を進めていく必要がある。

(Received December 9, 2016)

\section{文献}

1 ）産業情報調查会; 2015年版コネクター市場, p.2 (2015)

2 ）辻 清貴; 表面技術, 58,406 (2007)

3 ) 森内裕之; 表面技術, 59,218 (2008)

4 ）気賀智也, 浅井 正, 水口由紀子, 村上洋介, 田中伸史, 冨谷茂隆 ; エレクトロニクス実装学会誌, 11, 356 (2008).

5 ) JEITA ET-7305 : 2010, 錫ウイスカ抑制鉛フリー材料選定のガイ ドライン

6 ）藤間貞行; 表面技術, 63, 660 (2012)

7 ) 鶴 将嘉, 畚野 章; Kobe Steel Engineering Reports, 62, (2), 59 (2012) 